\title{
Akurasi Presentasi Web dengan Animasi Scalable Vector Graphics: Studi Kasus Animasi Pembelajaran Komunikasi bagi Anak Autis
}

\author{
Web Presentation Accuracy Using Scalable Vector Graphics Animation: A Case Study of \\ Communication Learning Animation for Autistic Children
}

\author{
Taryadi $^{1 *}$, Sattriedi Wahyu Binabar ${ }^{2}$, Era Yunianto $^{3}$ \\ 1,2,3Program Studi Sistem Informasi, STMIK Widya Pratama
}

\begin{tabular}{l}
\hline \hline ARTICLE INFO \\
\hline Article history: \\
DOI: \\
10.30595/pspfs.v1i.145 \\
Submitted: \\
June 21, 2021 \\
Accepted: \\
June 23, 2021 \\
Published: \\
Oct 31, 2021 \\
\hline
\end{tabular}

Keywords:

Animasi, Autism, CSS, HTML5, SVG

\begin{abstract}
In recent years, the use of the Web to quickly and efficiently run behavioral and social experiments has grown in popularity. However, there are still revenue differences related to the use of the Web for animation and multimedia. The analysis and accuracy of the use of web technology have been widely studied to update evidence on the accuracy and precession of presenting animation using the Web, as well as expanding research related to accuracy and precision in the presentation of multimedia and animation based on HTML5 technology, especially the use of scalable vector graphics (SVG). Presentation of visual content using web technology can be accepted with increasing accuracy and precision, although this technology needs consideration in some cases in its use. Accuracy and precision using CSS technology which is part of HTML, are the best alternatives for animation. The animation interval is above 50 milliseconds based on test results, while testing using SVG also shows results that are not much different from using CSS in animation. The performance of procedural web technology with HTML5 standards (CSS, SVG, and WebGL) is not much different from the analyzed web technology, with an average missed frame between 0.06 and 1.50 with a standard deviation between 0.252 and 1.055. This technology is becoming the standard and has a promising future, making its use more advisable than other technologies on the decline.
\end{abstract}

This work is licensed under a Creative Commons Attribution 4.0 International License.

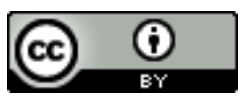

\author{
Corresponding Author: \\ Taryadi \\ Program Studi Sistem Informasi, STMIK Widya Pratama \\ J1. Patriot No. 25 Pekalongan \\ Email: pak tari.1218@gmail.com
}

\section{PENDAHULUAN}

Komputer telah menjadi alat yang sangat diperlukan untuk penelitian ilmiah sejak kemunculannya, bukan hanya karena kekuatan komputasinya tetapi juga karena kemampuannya untuk menyajikan informasi multimedia. Bahkan sebelum mempopulerkan antarmuka pengguna grafis, komputer telah digunakan untuk menyajikan rangsangan visual dalam aplikasi tachistoscopic yang tunduk pada batasan waktu yang ketat. Keberhasilan Web sebagai media komunikasi utama memfasilitasi pembuatan aplikasi eksperimental pertama berbasis teknologi web (Birnbaum, 2014).

Mengingat keragaman besar teknologi web, agen pengguna web, dan sistem operasi yang ada, ada beberapa kontroversi tentang kesesuaian penggunaan Web untuk tujuan ini. Untuk alasan ini, beberapa penelitian telah menganalisis keakuratan dan ketepatan teknologi web yang berbeda untuk menentukan keterbatasannya. Namun, pekerjaan yang ada tidak komprehensif (misalnya, GIF dan Silverlight belum dieksplorasi secara menyeluruh), dan tidak memeriksa opsi yang berbeda untuk mengontrol tampilan dalam HTML5 (misalnya, WebGL, Animasi CSS). Oleh karena itu, pembaruan tampaknya diperlukan (Schmidt, 2011); (Eichstaedt,2011). Tujuan dari penelitian ini adalah: (1) untuk memberikan pembaruan dari bukti yang ada tentang akurasi dan presisi presentasi Web dalam 
presentasi rangsangan animasi multimedia, dan (2) untuk memperluas studi ini ke teknologi terkait HTML5 yang masih belum teruji. Hasil penelitian ini memiliki implikasi bagi peneliti yang tertarik untuk mengembangkan eksperimen online di mana rangsangan harus disajikan di bawah persyaratan waktu yang ketat (misalnya, subliminal priming (Hassin, Ferguson, Shidlovski, Gross, 2017)) atau waktu reaksi harus diukur dengan tingkat tinggi akurasi dan presisi (Nosek, 2015) (Voss, Rothermund, Gast, Wentura, 2013).

Dalam animasi prosedural, objek dianimasikan dengan prosedur (skrip), bukan dengan mendefinisikan frame utama. Pengembang dapat memilih antara pendekatan yang berbeda untuk mengkodekan animasi yang diinginkan tergantung pada fitur tertentu dari perangkat lunak dan perangkat keras yang tersedia. Namun, animasi prosedural digabungkan erat dengan lingkungan yang berjalan (yaitu, perangkat keras, sistem operasi, versi agen pengguna web, dan sebagainya) dan mungkin terpengaruh oleh perubahan kecil padanya (Jackson, Hyatt, Marrin, Galineau, Baron, 2013).

HTML5 menyediakan berbagai macam mekanisme untuk membuat animasi. Pengembang web dapat menggunakan antarmuka pemrograman aplikasi (API) untuk membuat animasi deklaratif seperti Cascading Style Sheets (CSS) atau Scalable Vector Graphics Animations (SVG) dengan Synchronized Multimedia Integration Language (SMIL), atau animasi prosedural melalui SVG dengan JavaScript, HTML Canvas, atau WebGL (Reimers, Stewart, 2014). Ketidakakuratan yang terkenal dari pengatur waktu JavaScript standar (setTimeout dan setInterval) [Jackson] dapat dihindari dengan menggunakan kontrol waktu API animasi berbasis skrip (requestAnimationFrame) (Garaizar, Vadillo, López-de-Ipiña, Matute, 2014). Mempertimbangkan bahwa browser tetap mengontrol semua animasi yang berjalan menggunakan API ini, berada dalam posisi yang lebih baik untuk menentukan kecepatan frame optimal untuk menjalankan semua animasi semulus mungkin. Dalam paragraf berikut, kami memberikan gambaran umum tentang teknologi web ini.

SVG merupakan script XML untuk membuat gambar vektor (David, 2012). Di antara banyak fiturnya, memiliki kemampuan untuk menyematkan JavaScript atau menggunakan SMIL untuk membuat animasi deklaratif. Keuntungan menggunakan SMIL di SVG adalah: menyediakan informasi semantik tentang animasi, menghindari penghitung waktu JavaScript, dan membuat animasi yang dapat digunakan di luar browser (Plant, Quinlan, 2013). SVG dengan SMIL berbagi semua kelemahan Animasi CSS. Selain itu, dukungan untuk SMIL di sebagian besar browser modern tidak lengkap. Meskipun minat baru pada SVG karena HTML5, vendor browser telah mencurahkan lebih banyak upaya untuk mematuhi standar Animasi CSS daripada meningkatkan dukungan mereka terhadap SVG dengan SMIL.

\section{METODE PENELITIAN}

Tujuan dari Penelitian ini adalah melakukan analisis secara komprehensif untuk melihat presisi dan akurasi animasi yang dibuat menggunakan kombinasi teknologi web modern. Tahapan yang dilakukan dalam penelitian ini adalah sebagai berikut :

1. Melakukan analisis teknologi web untuk membuat animasi deklaratif: Animasi CSS dan SVG dengan SMIL. Selanjutnya menganalisis teknologi web untuk membuat animasi prosedural: SVG dengan JavaScript, Canvas, dan WebGL. Dalam semua pengujian animasi prosedural, API untuk Kontrol Temporal Animasi Prosedural (yaitu, requestAnimationFrame) digunakan untuk menghindari masalah yang terkait dengan penggunaan pengatur waktu JavaScript standar (setTimeout dan setInterval).

2. Mendefinisikan transisi keyframe hitam-ke-putih non-gradual, memvariasikan durasi setiap keyframe dengan nilai 500, 100, 50, dan 16,667 ms (yaitu, 30, 6, 3, dan 1 tick pada $60 \mathrm{~Hz}$, masing-masing). Semua tes terdiri dari animasi 200x200 piksel yang ditempatkan di tengah layar. Dalam setiap kasus dilakukan pencatatan lima seri independen 60 detik, tetapi hanya menganalisis 100 sampel pertama dari setiap seri. Oleh karena itu, 500 sampel dicatat untuk setiap kombinasi interval (500, 100, 50, dan 16,667 ms), teknologi web (Animasi CSS, SVG dengan SMIL, SVG dengan JavaScript, Canvas, dan WebGL) dengan menggunakan Google Chrome dengan sistem operasi Microsoft Windows.

3. Pengujian animasi deklaratif dengan menggunakan Animasi CSS dan SVG dengan SMIL, dan animasi prosedural yang disiapkan disiapkan dengan SVG.

4. Animasi CSS didefinisikan menggunakan dua keyframe. Yang pertama (dijalankan pada keyframe 0\%, yang menunjukkan momen pertama dari urutan animasi) mengatur warna latar belakang elemen div menjadi putih dan yang kedua (berjalan pada keyframe 50\%), mengaturnya kembali menjadi hitam.

\section{HASIL DAN PEMBAHASAN}

Sebelum menganalisis hasil penelitian kami, kami memutuskan untuk menghitung frame yang terlewat (missed frame), daripada kesalahan waktu terukur, karena beberapa alasan. Karena fokus dari studi ini adalah analisis akurasi dan presisi dari beberapa mekanisme perangkat lunak untuk membuat animasi untuk Web, kesalahan pengaturan waktu yang disebabkan oleh masalah perangkat keras (yaitu, waktu naik dan turunnya tampilan LCD) tidak boleh dianggap sebagai kesalahan perangkat lunak. Hal yang sama terjadi dengan keterbatasan dalam peralatan pengukuran 
(yaitu, fotosensor tidak memberikan nilai analog kontinu, melainkan digital diskrit berdasarkan ambang batas yang dapat disesuaikan).

Frame yang terlewat mewakili satu penyegaran layar (yaitu, 16,667 md pada $60 \mathrm{~Hz}$ ) dan konstan di semua kondisi. Frame yang terlewatkan bisa menjadi negatif dalam animasi di mana waktu presentasi setidaknya satu tik lebih pendek dari perkiraan durasi (misalnya, bingkai utama kosong $80 \mathrm{~ms}$ dalam animasi interval $100 \mathrm{~ms}$ ).

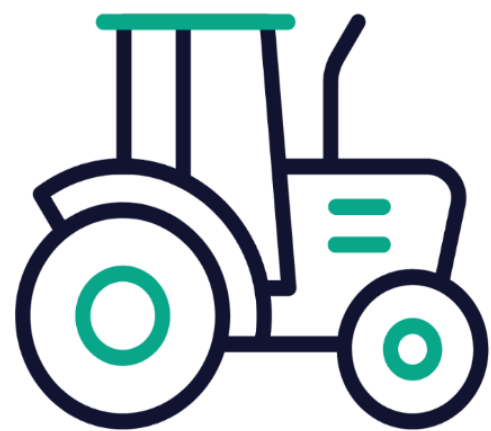

Gambar 1. Salah satu animasi traktor bergerak menggunakan SVG dalam animated tutor bagi anak Autism

Animated tutor yang dikembangkan dengan memanfaatkan teknologi web menampilkan animasi dari image dengan SVG dan digerakkan dengan menggunakan CSS. Penggunaan dari SVG dan CSS dalam aplikasi ini adalah untuk mengurangi kebutuhan sumber daya dan meningkatkan kecepatan dalam akses dan menampilkan animasi. Script yang digunakan untuk gambar traktor (lihat gambar 1) adalah sebagai berikut :

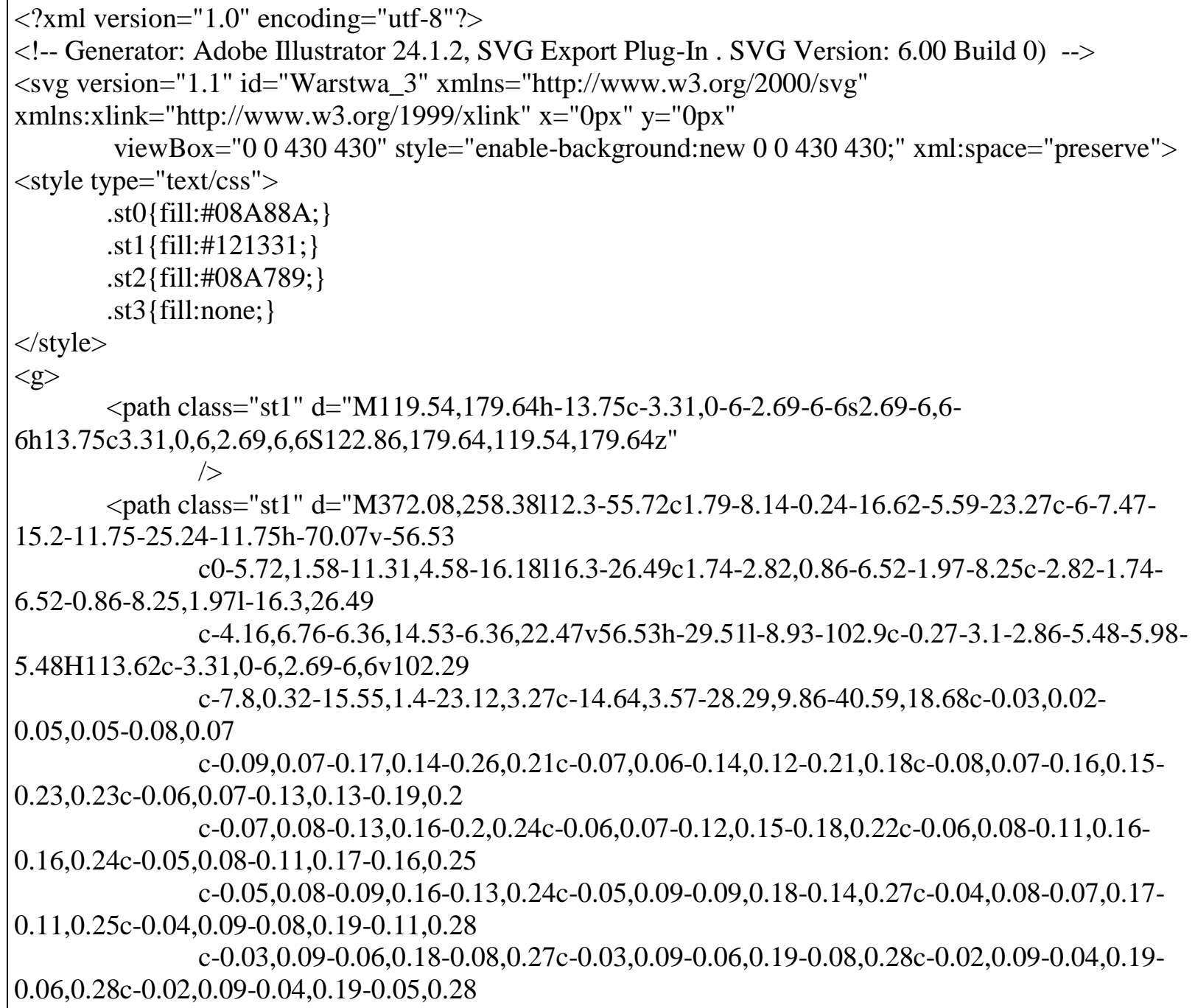




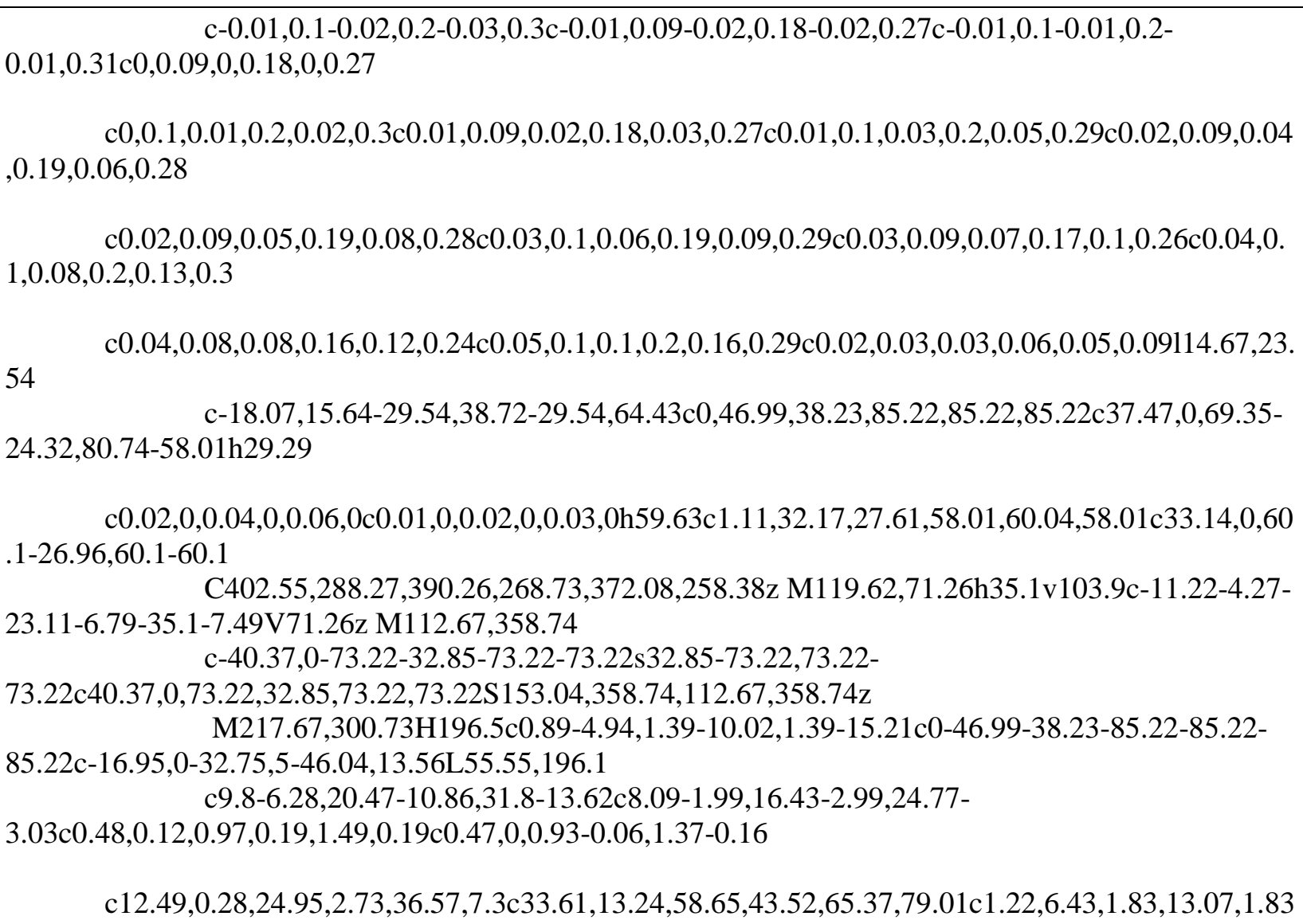
, 19.72

$\mathrm{C} 218.76,290.61,218.39,295.71,217.67,300.73 \mathrm{z}$

M166.72,180.52V71.26h54.8418.93,102.93c0,0.03,0,0.06,0.01,0.0917.32,84.39h-10.15

C219.8,225.14,197.18,196.3,166.72,180.52z M229.77,300.73c0.65-5.04,0.98-10.13,0.98$15.21 \mathrm{c} 0-4.97-0.32-9.94-0.93-14.84 \mathrm{~h} 14.54$

c1.68,0,3.29-0.71,4.42-1.94c1.14-1.24,1.7-2.9,1.56-4.571-7.33-

$84.52 \mathrm{~h} 110.54 \mathrm{c} 6.39,0,12.18,2.65,15.89,7.27$

c3.1,3.86,4.25,8.54,3.22,13.171-11.78,53.37c-5.81-1.88-12-2.9-18.42-2.9c-29.76,0-

$54.52,21.75-59.26,50.19 \mathrm{H} 229.77 \mathrm{z}$

M342.46,358.74c-26.52,0-48.1-21.58-48.1-48.1s21.58-48.1,48.1-

48.1s48.1,21.58,48.1,48.1S368.98,358.74,342.46,358.74z"/>

<path class="st2" d="M319.14,209.88h-37.61c-3.31,0-6-2.69-6-6s2.69-6,6-

6h37.61c3.31,0,6,2.69,6,6S322.46,209.88,319.14,209.88z"

/>

<path class="st2" d="M319.14,238.22h-37.96c-3.31,0-6-2.69-6-6s2.69-6,6-

6h37.96c3.31,0,6,2.69,6,6S322.46,238.22,319.14,238.22z"

/>

<path class="st2" d="M243.56,71.29H97.39c-3.31,0-6-2.69-6-6s2.69-6,6-

6h146.17c3.31,0,6,2.69,6,6S246.87,71.29,243.56,71.29z"/>

<path class="st2" d="M112.67,323.12c-20.74,0-37.61-16.87-37.61-37.6s 16.87-37.61,37.61-

37.61c20.74,0,37.6,16.87,37.6,37.61

S133.4,323.12,112.67,323.12z M112.67,259.91c-14.12,0-25.61,11.49-

25.61,25.61c0,14.12,11.49,25.6,25.61,25.6

c14.12,0,25.6-11.49,25.6-25.6C138.27,271.4,126.78,259.91,112.67,259.91z"/>

<path class="st2" d="M342.46,334.13c-12.95,0-23.49-10.54-23.49-23.49s 10.54-23.49,23.49-

23.49s $23.49,10.54,23.49,23.49$ 


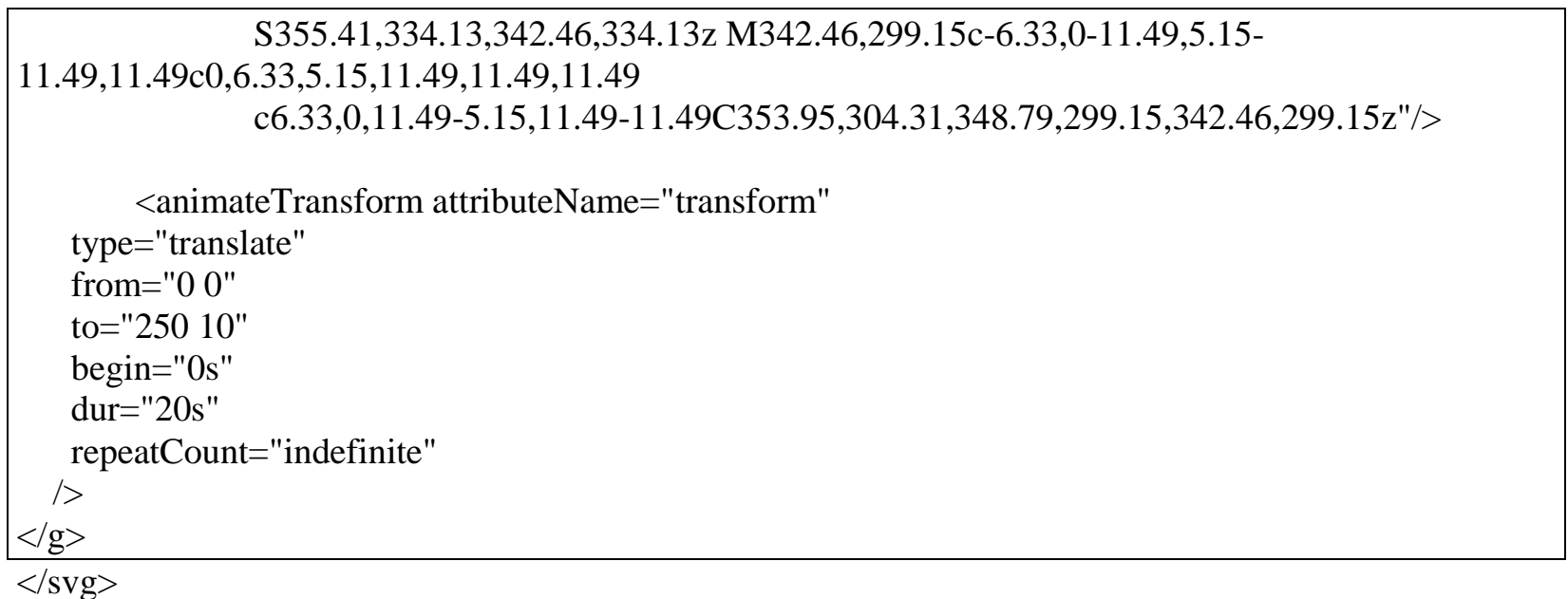

Tabel 1 menunjukkan hasil pengujian yang dilakukan dengan menggunakan CSS. Ada penurunan kinerja yang nyata dalam pengujian dengan interval di bawah $50 \mathrm{~ms}$, dengan hasil yang sangat buruk untuk Mozilla Firefox pada sistem operasi Windows (M: 4.89, SD: 5.041). Di atas interval itu, kinerja sebanding dengan hasil teknologi online klasik.

Tabel 1. Deskripsi statistik jumlah missed frame animasi dengan CSS

\begin{tabular}{lcccccccc}
\hline & \multicolumn{2}{c}{$\mathbf{5 0 0}$} & \multicolumn{2}{c}{$\mathbf{1 0 0}$} & \multicolumn{50}{c}{} & $\mathbf{1 6 . 6 6 7}$ \\
\hline Google Chrome & & & & & & & & \\
Mean (SD) & 0.06 & $(0.649)$ & 0.01 & $(0.522)$ & 0 & $(0.606)$ & 2.62 & $(0.79)$ \\
Range & -2 & +2 & -2 & +1 & -2 & +2 & +2 & +7 \\
$\begin{array}{l}\text { Mozzila Firefox } \\
\text { Mean (SD) }\end{array}$ & 0.06 & $(0.603)$ & 0.01 & $(1.043)$ & 0.01 & $(1.107)$ & 4.89 & $(5.041)$ \\
Range & -2 & +2 & -3 & +2 & -2 & +3 & 0 & +22 \\
\hline
\end{tabular}

Pengujian SVG dan SMIL menghasilkan pola hasil yang sangat mirip dengan yang diamati dalam pengujian Animasi CSS (lihat Tabel 2). Namun, penurunan kinerja dalam pengujian dengan interval di bawah $50 \mathrm{~ms}$ lebih jelas, menghasilkan hasil yang sangat buruk di Google Chrome pada Windows 10 (M: 24.69, SD: 44.167). Secara keseluruhan, kinerja kedua teknologi untuk animasi deklaratif sama atau lebih baik daripada yang diamati dalam pengujian setara teknologi web klasik, kecuali dalam kasus 16,667 md, di mana kinerja turun ke tingkat yang tidak dapat diterima. Seperti dapat dilihat pada Gambar 3, nilai-nilai ini tetap stabil, kecuali untuk kondisi 16.667 di SVG dan SMIL, yang mengalami peningkatan nyata dalam jumlah frame yang terlewat.

Tabel 2. Deskripsi statistik jumlah missed frame animasi dengan SVG+SMILL

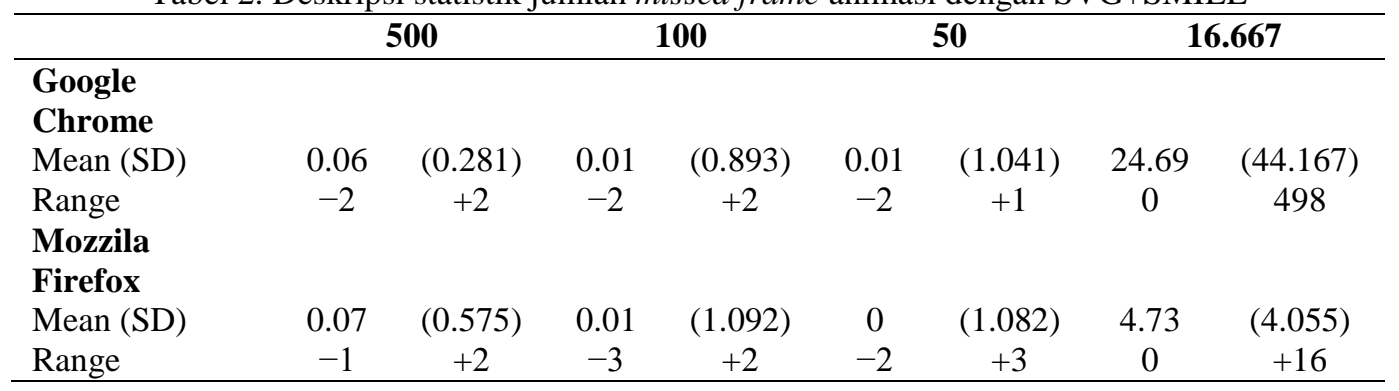

Perbandingan secara grafik dari pengujian dengan animasi dengan menggunakan CSS dan SVG+SMILL dapat dilihat pada gambar 2 dan gambar 3. Jumlah missed frame per seri animasi yang dibuat dengan CSS dan SVG+SMIL terlihat tidak terlalu berbeda jauh sesuai dengan hasil pengujian yang ditampilkan dalam tabel 1 dan tabel 2. 


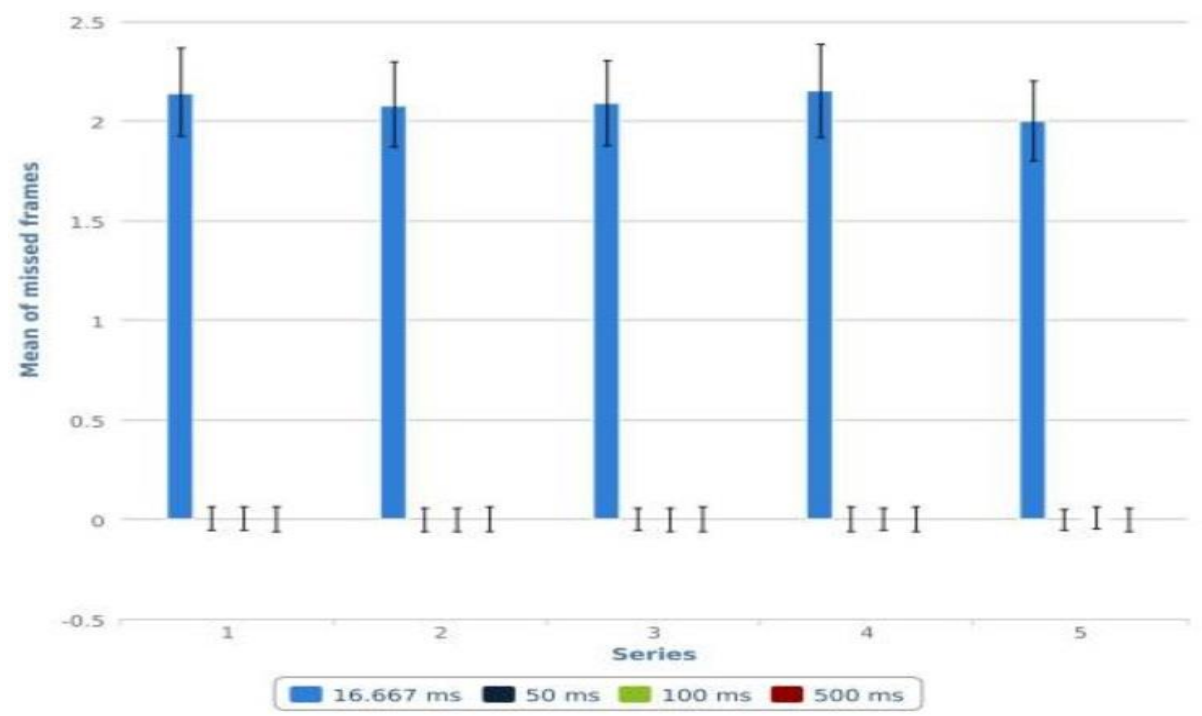

Gambar 2. Jumlah missed frame per seri animasi dengan CSS

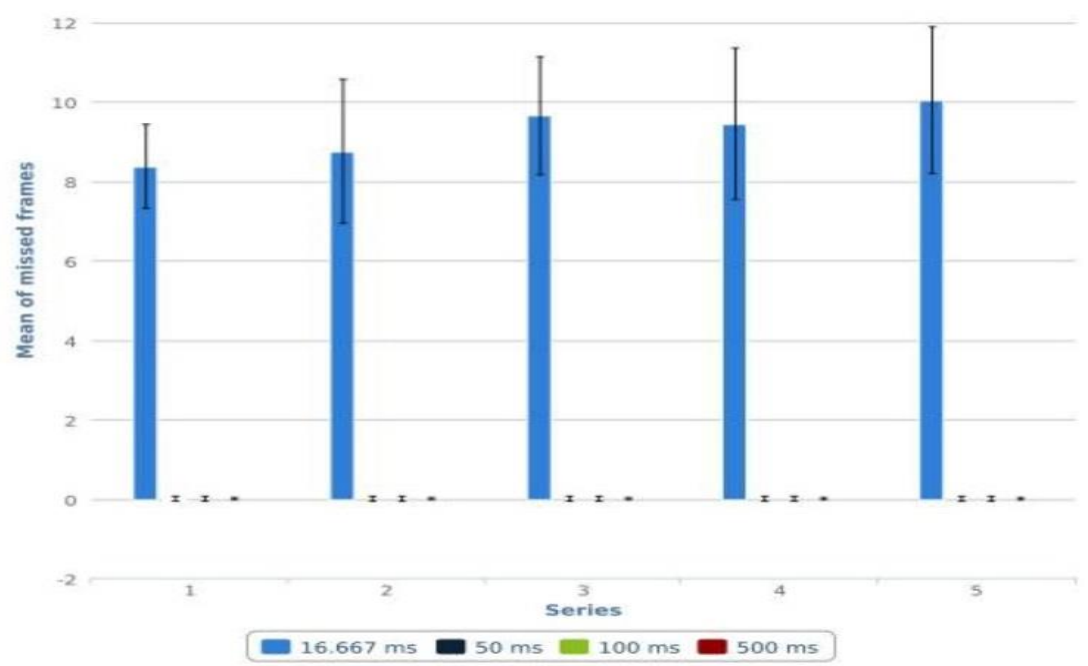

Gambar 3. Jumlah missed frame per seri animasi dengan SVG+SMIL

Untuk mendapatkan gambaran yang lebih jelas tentang faktor-faktor yang bertanggung jawab atas kinerja dalam pengujian ini, teknologi yang diuji adalah CSS, SMIL dan SVG dengan menggunakan perambah Google Chrome dan Mozilla Firefox, sistem operasi yang digunakan adalah Windows 10 dan interval pengujian pada detik ke 500, 100, 50, dan 16.667 dengan dua warna yang digunakan adalah Putih dan Hitam.

Hasil analisis yang didapatkan adalah 1) sebagai hasil dari sejumlah besar pengamatan, banyak efek mencapai tingkat signifikansi; 2) Efek utama Seri tidak signifikan, menunjukkan bahwa teknologi ini tidak mengalami degradasi temporal $(\mathrm{F}<1 ; 3)$ di antara semua efek utama yang dianalisis, efek utama Interval adalah yang paling relevan dalam hal ukuran efek, $\mathrm{F}(3,59999)=1127.896, \mathrm{p}<0.001, \eta \mathrm{p} 2=0.054$. Interaksi yang paling relevan adalah Technologi $\mathrm{x}$ Interval, $\mathrm{F}(24,59999)=695.966, \mathrm{p}<0.001, \eta p 2=0.124$, mungkin karena hasil yang buruk digambar oleh CSS dan SMIL dalam animasi 16,667 ms. Hasil ini konsisten dengan interpretasi sebelumnya tentang perbedaan yang ditemukan di seluruh interval, agen pengguna, dan sistem operasi. Namun, bahkan kedua efek ini memiliki ukuran yang sangat kecil.

Berdasarkan pembahasan yang dilakukan dapat disimpulkan bahwa, di antara semua teknologi yang diuji, animasi deklaratif berdasarkan CSS adalah alternatif yang paling efektif ketika interval animasi di atas 50 mili detik, mengingat bahwa teknologi ini menghasilkan sejumlah kecil frame yang terlewat (berarti dari 0,00 hingga $-0,06$, standar deviasi dari $0,459 \mathrm{ke} 1.107)$. Cara ini lebih stabil dengan tidak menghasilkan efek utama dari Seri atau interaksi 
penting yang melibatkan faktor ini, dan independen dari kinerja JavaScript (tidak membebani antrian dan juga tidak terpengaruh). Kesimpulan yang sama dapat diperluas ke kombinasi SVG dan SMIL, kecuali implementasinya yang kurang efisien di Google Chrome, yang menghalangi kinerja yang baik dan tidak memungkinkan perulangan temporal referensi silang.

Kinerja teknologi web prosedural dengan standar HTML5 (Canvas, SVG, dan WebGL dengan requestAnimationFrame) tidak berbeda jauh dengan teknologi web yang dianalisis sebelumnya (rata-rata frame yang terlewat antara 0,06 dan 1,50 dengan standar deviasi antara 0,252 dan 1,055, dibandingkan dengan rata-rata antara 0,00 dan 2,18 dan standar deviasi antara 0,109 dan 3,182). Selanjutnya, teknologi ini menjadi standar dan memiliki masa depan yang menjanjikan, yang membuat penggunaannya jelas lebih disarankan daripada teknologi lain yang penggunaannya semakin menurun (seperti : Java, Flash, Silverlight) (Reimers, Stewart, 2014).

\section{KESIMPULAN}

Hasil penelitian ini memiliki implikasi sebagai upaya untuk menerapkan studi perilaku dan sosial dalam teknologi online. Beberapa paradigma eksperimental populer memerlukan penyajian rangsangan visual yang sangat singkat dan akurat. Misalnya, percobaan pada priming subliminal biasanya memerlukan pemberian rangsangan dengan durasi antara 16 dan $100 \mathrm{~ms}$. Hasil pengujian menunjukkan bahwa tidak semua teknologi web sama validnya untuk mengembangkan aplikasi dengan batasan waktu yang ketat ini. Mengingat kinerja variabel agen-pengguna, pengatur waktu, dan teknologi, peneliti harus hati-hati memutuskan teknologi mana yang akan digunakan, tergantung pada persyaratan eksperimen yang ditetapkan.

Meskipun penelitian ini berfokus pada akurasi dan ketepatan durasi rangsangan, hasil yang didapat juga relevan untuk pengukuran waktu reaksi dalam eksperimen yang disampaikan melalui Web. Waktu reaksi dengan cepat menjadi variabel dependen umum dalam eksperimen psikologis yang dilakukan melalui Internet. Namun, akurasi dalam waktu rangsangan membatasi akurasi dalam pencatatan waktu reaksi: jika stimulus tidak disajikan pada waktu yang tepat atau dengan durasi yang tepat, waktu reaksi aktual peserta mungkin tidak dapat diukur dengan benar. Oleh karena itu, peneliti yang tertarik untuk mengumpulkan waktu reaksi dalam eksperimen yang disampaikan melalui Web harus memastikan bahwa menggunakan teknologi yang paling akurat untuk waktu rangsangan.

\section{UCAPAN TERIMA KASIH}

Ucapan terima kasih peneliti sampai kepada Direktorat Riset dan Pengabdian Masyarakat Dirjen Dikti Kementrian Pendidikan, Kebudayaan, Riset dan Teknologi Republik Indonesia yang telah mendanai penelitian tahun 2021 ini dengan nomor kontrak penelitian 312/SP2H/LT/DRPM/2021 dan dengan Lembaga Layanan Pendidikan Tinggi Wilayah 6 Jawa Tengah dengan Nomor kontrak : 56/LL6/PG/SP2H/JT/2021.

\section{DAFTAR PUSTAKA}

Birnbaum, MH. (2014) Human research and data collection via the Internet, Annu Rev Psychol, 55, 803-832.

David, J.E. (2002) SVG Essentials, O'Reilly.

Eichstaedt, J. (2011) An inaccurate-timing filter for reaction time measurement by Java applets implementing Internetbased experiments, Beh Res Methods, 33(2): 179-186.

Garaizar, P., Vadillo, MA., López-de-Ipiña, D., Matute, H, (2014) Measuring software timing errors in the presentation of visual stimuli in cognitive neuroscience experiments, PLoS ONE 9(1): e85108.

Hassin. RR., Ferguson, MJ., Shidlovski, D., Gross, T. (2017) Subliminal exposure to national flags affects political thought and behavior, Proc Natl Acad Sci U S A, 104: 19757-19761.

Jackson, D., Hyatt, D., Marrin, C., Galineau, S., Baron, D. (2013) CSS animations. W3C Working Draft, 19 February 2013. Available: http://www.w3.org/TR/css3-animations/

Nosek, BA. (2015) Moderators of the relationship between implicit and explicit evaluation, Journal Exp Psychol: General, 134, 565-584.

Plant, RR., Quinlan, PT. (2013) Could millisecond timing errors in commonly used equipment be a cause of replication failure in some neuroscience studies? ,Cogn Affect Behav Ne, 13: , 598-614.

Reimers, S., Stewart, N. (2014) Presentation and response timing accuracy in Adobe Flash and HTML5/JavaScript Web experiments, Beh Res Methods, doi:10.3758/s13428-014-0471-1.

Schmidt, W. (2011) Presentation accuracy of Web animation methods. Beh Res Methods, 33(2): 187-200.

Voss, A., Rothermund, K., Gast, A., Wentura, D. (2013) Cognitive processes in associative and categorical priming: A diffusion model analysis, Journal Exp Psychol: General, 142: 536-559. 